\author{
Jernej Habjan, Rastko Močnik
}

\title{
Kaj je sociologija kulture danes?
}

Pričujoči tematski sklop o sociologiji kulture je nastal iz delavnice Kaj je sociologija kulture danes?, ki smo jo 12. decembra 2011 pripravili v okviru zasedbe Filozofske fakultete. ${ }^{1} \mathrm{Na}$ njej so s prispevki sodelovali: Branko Bembič, Maja Breznik, Jernej Habjan, Gorazd Kovačič, Primož Krašovec, Marko Kržan, Aldo Milohnić, Igor Škamperle in Rastko Močnik. Sprva smo hoteli razpravljati o dveh tesno prepletajočih se problematikah: kaj je obča sociologija danes in kaj je sociologija kulture danes. A na prošnjo predstojnice oddelka za sociologijo smo naslov omejili samo na sociologijo kulture.

Na Oddelku za sociologijo Filozofske fakultete Univerze v Ljubljani smo že leta 1999 predlagali, da bi pripravili znanstveno srečanje o problematiki sociologije in sociologije kulture ter o teoretskih in pedagoških praksah na tem področju. Drugič smo tak posvet predlagali ob pripravah na bolonjsko reformo. Pristojni na oddelku za sociologijo so predlog obakrat zavrnili. Šele z zasedbo fakultete je bilo mogoče sprožiti teoretsko razpravo o disciplini, za katero je oddelek za sociologijo matičen na ljubljanski univerzi.

Pričujoči tematski sklop precej zvesto predstavlja sedanje teoretske prakse $\mathrm{v}$ sociologiji kulture. Sklop seveda ni popoln, zlasti zato, ker nekateri znanstveniki in znanstvenice, ki so z dragocenimi prispevki obogatili delavnico, niso utegnili sodelovati pri tukajšnji objavi. Marko Kržan v epistemološki razpravi določa strukturne sestavine in epistemični kraj teoretskega spoznavnega predmeta »kultura « v polju historičnega materializma. Maja Breznik na naivno vprašanje »Kaj je kultura? « odgovarja z nenaivno tezo, da je kultura lahko družbeno razdiralna; tezo argumentira z zgodovinskimi zgledi. Branko Bembič analizira kulturne sestavine ekonomskih bojev delovnih razredov $\mathrm{v}$ kapitalizmu ter ob tem predlaga koncepte za raziskavo delavskih kultur in sodobnih praks odpora. Primož Krašovec analizira postsocialistične ideologije in njihove učinke; ugotavlja, da se mora teorija ob zgodovinski izčrpanosti kapitalizma še zlasti skrbno posvetiti postkapitalističnim prvinam v sodobnih družbenih procesih. Jernej Habjan razvija analitično zgodovino prešernoslovske problematike od NOB in socialistične revolucije do danes; prikazuje napetosti in trke med ideološkimi pritiski in teoretskimi praksami na privilegiranem področju tukajšnjega humanističnega raziskovanja. Ana Podvršič analizira dosežke in pomanjkljivosti raziskovanja »romskega vprašanja« ter razmišlja o pozitivnem programu, ki bi to problematiko odrešil ideološkega pritiska

1 http://mismouniverza.org/javna-tribuna-kaj-je-sociologija-kulture-danes/. 
identitetnih politik in študij ter jo umestil v produktivno teoretsko polje historičnega materializma. Sašo Furlan predstavlja Marxov epistemološki doprinos in razvija predpostavke za teoretsko produkcijo v družboslovju in humanistiki. Tibor Rutar analizira ideološke podmene postmodernistične kvaziteorije in zlasti kritično obdeluje postmodernistično interpretacijo Marxa. Rastko Močnik zgoščeno predstavlja teoretsko problematiko sociologije kulture v zadnjih dvajsetih letih. Gorazd Kovačič opisuje teoretsko in institucionalno zgodovino sociologije kulture v njenih odnosih do obče sociologije na Oddelku za sociologijo Filozofske fakultete, ki je matični oddelek za sociologijo kulture na Univerzi v Ljubljani.

Sklopu smo dodali seznam izvirnih knjižnih izdaj s področja sociologije kulture v slovenščini. Ker je sociologija kulture že nekaj časa brez ustrezne institucionalne podpore, so njeni dosežki, zlasti v akademski javnosti, manj znani. S seznamom želimo tudi univerzitetno javnost seznaniti z novejšo produkcijo v tej disciplini. 